\title{
Mid-level convection in a warm conveyor belt accelerates the jet stream
}

\author{
Nicolas Blanchard ${ }^{1}$, Florian Pantillon ${ }^{1}$, Jean-Pierre Chaboureau ${ }^{1}$, and Julien Delano ${ }^{2}$ \\ ${ }^{1}$ Laboratoire d'Aérologie, Université de Toulouse, CNRS, UPS, Toulouse, France \\ ${ }^{2}$ LATMOS/IPSL, Université Paris-Saclay, UVSQ, Sorbonne Université, CNRS, Guyancourt, France
}

Correspondence: Florian Pantillon (florian.pantillon@ aero.obs-mip.fr)

Received: 14 October 2020 - Discussion started: 16 October 2020

Revised: 12 January 2021 - Accepted: 14 January 2021 - Published: 18 January 2021

\begin{abstract}
Jet streams and potential vorticity (PV) gradients along upper-level ridges, troughs and zonal flows form a waveguide that governs midlatitude dynamics. Warm conveyor belt (WCB) outflows often inject low-PV air into ridges, and the representation of WCBs is seen as a source of uncertainty for downstream forecasts. Recent studies have highlighted the presence of mesoscale structures with negative PV in WCBs, the impact of which, on large-scale dynamics, is still debated. Here, fine-scale observations of cloud and wind structures acquired with airborne Doppler radar and dropsondes provide rare information on the WCB outflow of the Stalactite cyclone and the associated upper-level ridge on 2 October 2016 during the North Atlantic Waveguide and Downstream Impact Experiment (NAWDEX). The observations show a complex tropopause structure associated with two jet stream cores along the northwestern edge of the ridge. A reference convection-permitting simulation with full physics reproduces the observed structures and reveals the presence of elongated negative PV bands along the eastern jet stream core. In contrast, a sensitivity experiment with heat exchanges due to cloud processes being cut off shows lower cloud tops, weaker jet stream cores, a ridge less extended westward and the absence of negative PV bands. A Lagrangian analysis based on online trajectories shows that the anticyclonic branch of the WCB outflow enters the eastern jet stream core in the reference simulation, while it is absent in the sensitivity experiment. The anticyclonic ascents and negative PV bands originate from the same region near the cyclone's bent-back front. The most rapid ascents coincide with mid-level convective cells identified by clustering analysis, which are located in a region of conditional instability below the jet stream core and above a low-level jet. Hori-
\end{abstract}

zontal PV dipoles are found around these cells, with the negative poles reaching absolute negative values, and the convective cells thus appear as the source of the negative PV bands. The results show that mid-level convection within WCBs accelerates the jet stream and may influence the downstream large-scale circulation.

\section{Introduction}

Jet streams and potential vorticity (PV) gradients along upper-level ridges, troughs and zonal flows form a waveguide that governs the propagation of Rossby waves (Hoskins and Ambrizzi, 1993). Rossby waves are the main drivers of midlatitude dynamics, constrain the formation of surface cyclones and anticyclones and act as precursors to high-impact weather events. An accurate representation of jet streams and PV gradients is therefore crucial in numerical weather prediction systems. However, it has been found that the PV gradient across the tropopause, adjacent to ridges, and the amplitude of Rossby waves decrease with lead time in global model forecasts to about $5 \mathrm{~d}$ (Gray et al., 2014; MartínezAlvarado et al., 2018). More recently, it has been shown that analyses and short-term forecasts tend to underestimate the peak jet stream wind, the vertical wind shear and the abruptness of the change in wind shear across the tropopause (Schäfler et al., 2020). This calls for a better understanding of processes controlling PV gradients.

Warm conveyor belt (WCB) outflows are one of the main perturbations to the midlatitude waveguide. WCBs usually flow poleward and upward as coherent airstreams associated with extratropical cyclones (Harrold, 1973; Wernli and 
Davies, 1997). Rising with rates not exceeding $50 \mathrm{hPa} \mathrm{h}^{-1}$, the warm and moist air in WCBs cools and condenses to form wide, elongated bands of cloud in which heavy precipitation and strong surface winds occur (Browning, 1999). During WCB ascents, a large amount of latent heating is released by cloud processes, the representation of which is considered a major source of uncertainty (Chagnon et al., 2013; MartínezAlvarado et al., 2014; Joos and Forbes, 2016). This source can be explained from the PV perspective, where PV is produced below the level of maximum heating and reduced above (Hoskins et al., 1985). In WCBs, vertical PV dipoles are created with positive PV anomalies in the lower layers and negative PV anomalies in the upper layers (Wernli and Davies, 1997). The low-PV air resulting from the negative anomalies is then transported into the upper-level ridge by the WCB outflow, where it is advected toward high-PV air by the associated divergent wind, and this impacts both the jet stream and the PV gradient at the tropopause (Grams et al., 2011). Accordingly, errors in the PV change by cloud processes lead to errors at upper levels (e.g., Maddison et al., 2019).

Recent studies have shown the presence of mesoscale negative PV structures in WCBs (Harvey et al., 2020; Oertel et al., 2020; Blanchard et al., 2020). Harvey et al. (2020) developed a theory explaining that diabatic heating in the presence of vertical wind shear results in negative PV values on the equatorward side of the jet stream. Oertel et al. (2020) showed, with a composite analysis, that convective ascents produce horizontal PV dipoles, which persist for about $10 \mathrm{~h}$ and merge to form elongated negative PV bands that can locally accelerate the jet stream. Blanchard et al. (2020) showed that, among three types of organized convection they found in a WCB region, only mid-level convection is associated with coherent negative PV bands. These studies further suggest that the mesoscale negative PV structures may accelerate the jet stream locally and potentially influence the downstream circulation.

This paper is focused on the WCB outflow of the Stalactite cyclone observed during the North Atlantic Waveguide and Downstream Impact Experiment (NAWDEX; Schäfler et al., 2018). The cyclone was named after the low tropopause whose shape was reminiscent of stalactite - during its intensification phase. On 2 October 2016, the WCB outflow was sampled with airborne instruments with the objective being to characterize its role in the building of the downstream ridge. A total of $2 \mathrm{~d}$ later, this ridge became a block over Scandinavia and persisted for several weeks (Schäfler et al., 2018). Previous studies showed the major role of diabatic heating in the Stalactite cyclone's WCB on the subsequent onset of blocking (Maddison et al., 2019, 2020; Steinfeld et al., 2020). Maddison et al. (2019) conducted an ensemble sensitivity analysis in which the Stalactite cyclone is clearly identified as the main feature influencing the block onset 3-4 d ahead. Maddison et al. (2020) showed, through several sensitivity experiments with a convective parameter- ization in a global model, that stronger latent heating in the WCB leads to a more amplified ridge after a $6 \mathrm{~d}$ lead time. Steinfeld et al. (2020) found a strong influence of latent heating in the Stalactite cyclone on the ridge building after $2 \mathrm{~d}$ of simulations.

The objective of this study is to examine the WCB outflow at the fine scale and to investigate the cloud diabatic effects in the WCB during a relatively short $12 \mathrm{~h}$ window. To achieve this objective, we use the convection-permitting simulation described in Blanchard et al. (2020) and run a second simulation set up in the same manner, except with the diabatic impact of clouds turned off. We compare both simulations with airborne Doppler radar and dropsonde measurements taken in the WCB outflow. After showing the cloud diabatic effects in the northwestern edge of the ridge, we trace them back to mid-level convection that occurs in the western flank of the WCB a few hours earlier.

The paper is structured as follows: Sect. 2 briefly introduces the observations and the model simulations and numerical tools used for the analysis. Section 3 describes, in detail, the airborne observations of the ridge and WCB outflow. Section 4 characterizes the ascents ending in the WCB outflow by studying their Lagrangian back-trajectories, while distinguishing between those with an anticyclonic and a cyclonic curvature. Section 5 focuses on the origin of PV structures in the observed regions before discussing the link with mid-level convective ascents within the WCB. Section 6 concludes the paper.

\section{Data and methods}

\subsection{Airborne observations}

Cloud radar RASTA (RAdar Airborne System; Delanoë et al., 2013) and dropsonde observations were acquired from the SAFIRE (Service des Avions Français Instrumentés pour la Recherche en Environnement) Falcon 20 based in Keflavik, Iceland. On the morning of 2 October 2016, the Falcon 20 flew toward Greenland with the objective of studying the tropopause structure and the WCB outflow from the Stalactite cyclone (flight 6 in Schäfler et al., 2018, see the track in Fig. 1a). During its cruise, the aircraft flew at around $10 \mathrm{~km}$ altitude. On its way back to Iceland, four Vaisala RD94 dropsondes were launched at 10:26, 10:32, 10:36 and 10:41 universal coordinated time (UTC). In the following, we will discuss the profiles of wind speed, potential temperature and relative humidity (with respect to liquid water below the melting level and to ice above) obtained from the dropsondes as well as the reflectivity and wind speed obtained from RASTA between 10:25 and 11:27 UTC (hereinafter referred to as the 11:00 UTC leg). The reader is referred to Blanchard et al. (2020) and the references therein for more details on RASTA operated on 2 October 2016. 

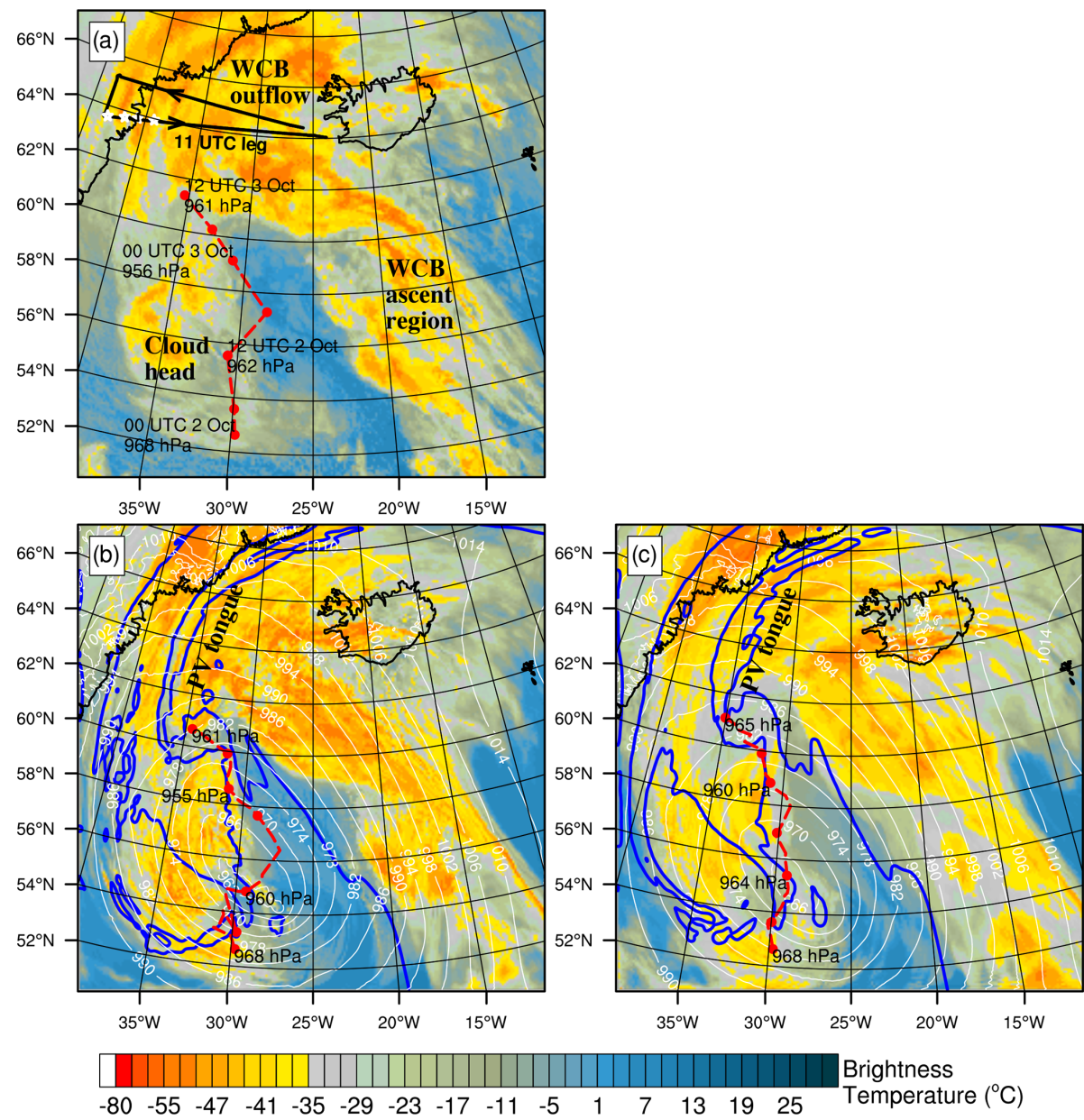

Figure 1. The $10.8 \mu \mathrm{m}$ brightness temperature (in ${ }^{\circ} \mathrm{C}$ ) at 11:00 UTC, 2 October 2016, as (a) observed by the Meteosat Second Generation (MSG) satellite and simulated by (b) REF (reference simulation) and (c) NODIA (sensitivity simulation). In (b) and (c), mean sea level pressure (MSLP) is shown with white contours every $4 \mathrm{hPa}$ between 964 and $1016 \mathrm{hPa}$, and the smoothed $2 \mathrm{PVU}$ at $320 \mathrm{~K}$ is shown with blue contours. In (a)-(c), the cyclone track and value of the MSLP minimum are shown (red dotted line; red mark every $6 \mathrm{~h}$ ) for the ECMWF (European Centre for Medium-Range Weather Forecasts) analysis and the REF and NODIA simulations. The MSLP minimum is tracked every $6 \mathrm{~h}$ within a radius of $250 \mathrm{~km}$ from its prior position in the ECMWF analysis and every $1 \mathrm{~h}$ within a radius of $160 \mathrm{~km}$ in the simulations. In (a), the black line shows the track of the Falcon 20 aircraft and the 11:00 UTC leg, whereas the white stars show the location of the dropsondes shown in Fig. 4.

\subsection{Meso-NH convection-permitting simulations}

Two simulations, REF (the reference simulation) and NODIA (the sensitivity simulation), were performed with version 5.3 of the non-hydrostatic mesoscale atmospheric Meso-NH model (Lac et al., 2018) over the domain shown in Fig. 1. Both simulations are convection permitting, with a grid spacing of $2.5 \mathrm{~km}$ horizontally and vertically from $60 \mathrm{~m}$ near the surface to $600 \mathrm{~m}$ in the upper levels. They are run from 00:00 UTC, 2 October 2016 to 12:00 UTC, 3 October with hourly outputs and initial and boundary conditions provided by the ECMWF (European Centre for Medium-Range Weather Forecasts) operational analyses. Both simulations share the same parameterizations, differing only in that the heat exchanges in the cloud microphysical scheme are set to zero in NODIA. Note that the other parameterizations (radiation, turbulence and shallow convection) also exchange heat in the atmosphere, but in a negligible way compared to cloud processes. The REF simulation is described in Blanchard et al. (2020), where more details are given on the parameterizations and on the radiative tools used to emulate the RASTA and Meteosat Second Generation (MSG) satellite observations. Following Söhne et al. (2008), we compare synthetic and satellite observations to compute the categorical Heidke skill score (HSS), which measures the fraction of correct forecasts after eliminating those that would be correct by chance. 


\subsection{Lagrangian trajectory and clustering tools}

Lagrangian trajectories are calculated online by initializing passive tracers at each grid point in the simulation domain (Gheusi and Stein, 2002). Three scalar tracers per grid point allow us to follow the 3D position of each air parcel. These tracers are advected by the piecewise parabolic method scheme (Colella and Woodward, 1984), which is known to conserve the mass properties of the tracers with a weak numerical diffusion well. Back-trajectories are reconstructed from the tracers and are studied for the period from 00:00 until 12:00 UTC on 2 October. This relatively short time window is chosen to ensure that all relevant trajectories remain in the simulation domain during the $12 \mathrm{~h}$ period. As in Blanchard et al. (2020), trajectories rising by at least $150 \mathrm{hPa}$ in $12 \mathrm{~h}$ are defined as ascents. This threshold is based on the usual criterion of $600 \mathrm{hPa}$ in $48 \mathrm{~h}$ used to identify WCB trajectories (e.g., Wernli and Davies, 1997; Martínez-Alvarado et al., 2014; Oertel et al., 2020) but without any constraint on the initial altitude of the trajectories, which is in contrast with previous studies. Selected ascents, thus, do not perform a full ascent from the boundary layer to the upper troposphere and may not all belong to actual WCB trajectories (see Blanchard et al., 2020, for a discussion).

Coherent structures within the WCB are detected with the clustering tool created and implemented in Meso- $\mathrm{NH}$ by Dauhut et al. (2016). Coherent updraft structures consist of 3D objects made of connected grid points for which the vertical velocity is higher than a threshold of $0.3 \mathrm{~m} \mathrm{~s}^{-1}$, as in Blanchard et al. (2020). In the same way, coherent negative PV structures are defined as areas of connected grid points, with $\mathrm{PV}$ values lower than $-1 \mathrm{PVU}$ (1 PVU $=10^{-6} \mathrm{~K} \mathrm{~kg}^{-1} \mathrm{~m}^{2} \mathrm{~s}^{-1}$ ).

\section{Observations of the upper-level ridge at 11:00 UTC}

\subsection{Overview}

An overview of the cloud structures of the Stalactite cyclone and of the associated upper-level ridge is first given. At 11:00 UTC on 2 October, the Stalactite cyclone approached Iceland, as shown by the infrared MSG brightness temperature (BT; Fig. 1a). The elongated band of primarily high clouds observed in the southeastern part of the simulation domain (BT values less than $-35^{\circ} \mathrm{C}$ ) locates the WCB ascent region. High clouds are also present in the northern and partly southwestern parts of the domain and indicate the WCB outflow and cloud head regions, respectively. Midlevel clouds are also detected in these regions (BT values between -35 and $0{ }^{\circ} \mathrm{C}$ ). Positive BT values locate the dry intrusion between the cloud head and WCB ascent regions. Some isolated low-level clouds are observed below the dry intrusion. The aircraft crossed the WCB outflow region when flying back to Keflavik during the 11:00 UTC leg.
In REF, the position of the main cloud structures is correctly reproduced, although high clouds are more spatially extended in the cloud head and WCB regions (Fig. 1b). The smoothed 2 PVU contour at the $320 \mathrm{~K}$ level (blue line) shows that the upper-level ridge, defined as the low PV region, covers the northeast for three quarters of the domain. It also highlights a complex PV structure over the cloud head and above the Greenland coast. North of $60^{\circ} \mathrm{N}$, a tongue of high $\mathrm{PV}$ value with relatively low cloud tops cuts the northwestern edge of the ridge in two parts.

In NODIA, the main cloud structures are also reproduced but with higher BT values than in the MSG observation and REF in the cloud head and WCB regions (Fig. 1c). Cloud tops are therefore expected to be lower in these regions. However, the Heidke skill score for BT values below $-35^{\circ} \mathrm{C}$ is similar for both simulations when compared to MSG $(\sim 0.7)$, which shows that the general pattern of high clouds is not strongly impacted in NODIA. Note that the dry intrusion extends less to the northwest. The 2 PVU contour shows a pattern similar to REF but with the PV tongue shifted eastward and fewer small-scale structures present.

The location of the mean sea level pressure (MSLP) minimum of the Stalactite cyclone, represented by the red dotted lines during the simulated $36 \mathrm{~h}$ period, shows that the cyclone moves northward on the morning of 2 October. In the ECMWF analysis (Fig. 1a), an abrupt eastward shift then occurs between 12:00 UTC on 2 October and 00:00 UTC on 3 October as the cyclone deepens and finally moves northwestward towards the Greenland Plateau. The track of the Stalactite cyclone is well reproduced in REF, including the abrupt eastward shift and its deepening from 968 to around $955 \mathrm{hPa}$ (Fig. 1b). In NODIA, the MSLP minimum values are higher by $\sim 5 \mathrm{hPa}$ compared to ECMWF and REF (Fig. 1c). In addition, the abrupt eastward shift is not reproduced, resulting in a more meridional cyclone track. The abrupt shift is due to the creation of a second MSLP center to the east (see MSLP at 16:00 UTC in Fig. 1b in Blanchard et al., 2020), which therefore has a diabatic origin.

\subsection{Vertical structure of the upper-level ridge across the flight leg}

In the following, we focus on the WCB outflow region overflown by the Falcon 20 aircraft along the 11:00 UTC leg. Its track is indicated by the black lines in Fig. 1a, while the location of the dropsondes launched during the flight are marked by white stars. The observations of the RASTA radar and the dropsondes, combined with the REF results, provide a finescale description of the upper-level dynamics in the region.

The vertical structure of reflectivity, as seen by RASTA, shows a large cloud system between 43.5 and $27^{\circ} \mathrm{W}$ (Fig. 2a). Weak reflectivity values (about $-20 \mathrm{dBZ}$ ) are measured above $\approx 7 \mathrm{~km}$ altitude. These values are characteristic of cirrus-type clouds. Their location is consistent with the strong negative BT values shown in Fig. 1a. Reflectivity 


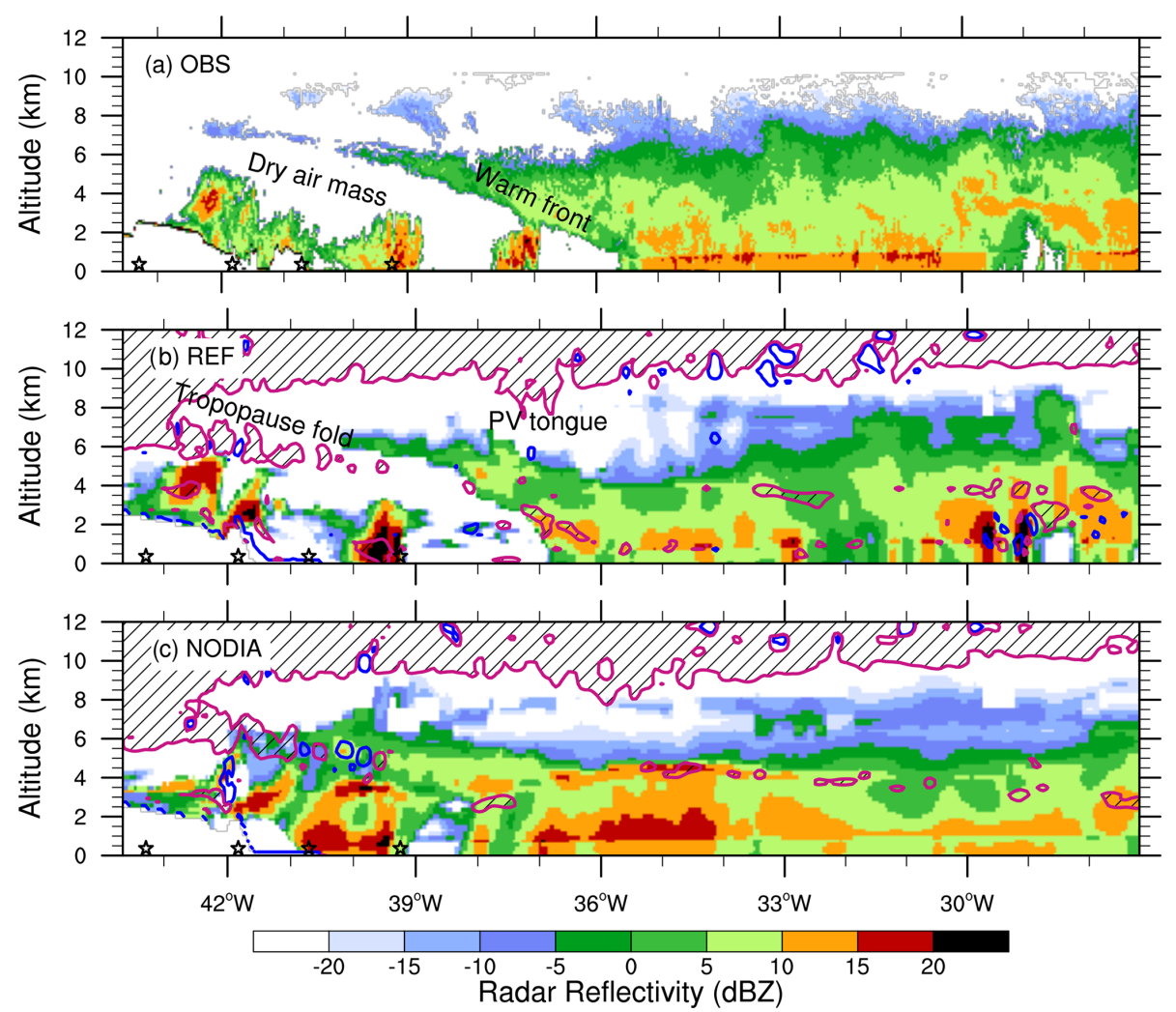

Figure 2. Reflectivity, in dBZ (a), measured by RASTA and simulated by (b) REF and (c) NODIA along the 11:00 UTC leg (black line in Fig. 1). The black stars show the position of the dropsondes shown in Fig. 4. In (b) and (c), magenta and navy blue contours show PV values equal to 2 and -1 PVU, respectively, with hatching for PV values greater than 2 PVU.

values then increase below $\mathrm{z} \approx 7 \mathrm{~km}$. Reflectivity values of $10 \mathrm{dBZ}$ are measured in the first kilometer of altitude, with local peaks greater than $15 \mathrm{dBZ}$ at $z \approx 1 \mathrm{~km}$ highlighting the melting level. They are lower between 1 and $\approx 7 \mathrm{~km}$ altitude, with local peaks of $10 \mathrm{dBZ}$. The slope in the vertical structure of reflectivity between 40 and $35.5^{\circ} \mathrm{W}$ reveals the warm front associated with the cyclone and indicates the location of the cold conveyor belt. Isolated convective structures, highlighted by the reflectivity values greater than $15 \mathrm{dBZ}$, are present below around 39 and $37^{\circ} \mathrm{W}$ and above the Greenland Plateau around $42^{\circ} \mathrm{W}$. The lack of radar signal (lower than $-20 \mathrm{dBZ}$ ) between the warm front slope and the isolated convective structures suggests the presence of a dry air mass. This dry air mass in the mid levels is hardly detectable on the BT field in Fig. 1a.

The WCB outflow region, the slope of the warm front, the isolated convective structures and the dry air mass are well reproduced by REF, with reflectivity values similar to those observed (Fig. 2b). The $2 \mathrm{PVU}$ contour shows the PV tongue between $37-38^{\circ} \mathrm{W}$, which penetrates the troposphere down to $z \approx 8 \mathrm{~km}$. It also reveals a tropopause fold west of $40^{\circ} \mathrm{W}$, reaching $z \approx 6 \mathrm{~km}$, which covers the upper part of the dry air mass. Note the spots of negative PV at the tropopause in the eastern part of the domain. In NODIA, the vertical struc- ture of reflectivity shows higher values around the melting level and mid levels compared to the RASTA observation and REF (Fig. 2c). This can be explained by higher contents of frozen hydrometeors (graupel and snow at the melting level and mid levels, respectively) due to the cut-off of diabatic heating from cloud processes. The upper levels are also impacted. The level of the cloud top in the eastern part does not exceed $\approx 7 \mathrm{~km}$ altitude, while it is higher than $z=8 \mathrm{~km}$ in the observation and REF. Moreover, the tropopause fold and the PV tongue are shifted eastward compared to those simulated in REF. Finally, the dry air mass is not reproduced in NODIA. This can be explained by a lower evaporation of frozen hydrometeors under the warm slope due to the cut-off of diabatic cooling from cloud processes.

The vertical structure of the horizontal wind speed measured by RASTA shows, in part, the jet stream with values greater than $25 \mathrm{~m} \mathrm{~s}^{-1}$ above $z \approx 7 \mathrm{~km}$ (in yellow in Fig. 3a). Local peaks of $40 \mathrm{~m} \mathrm{~s}^{-1}$ are measured in the upper levels (in red). The horizontal wind speed decreases below. It is quite homogeneous in the middle and low levels (around $10 \mathrm{~m} \mathrm{~s}^{-1}$ ), except in the eastern part of the domain where it reaches $20 \mathrm{~m} \mathrm{~s}^{-1}$ between 2 and $6 \mathrm{~km}$ altitude. Horizontal wind speeds greater than $25 \mathrm{~m} \mathrm{~s}^{-1}$ below $z=2 \mathrm{~km}$ around 42 and $39^{\circ} \mathrm{W}$ show the presence of a low-level jet along the 
Greenland coast. The low-level jet likely corresponds to the cold conveyor belt, with possible orographic influence.

The vertical structure of the horizontal wind speed in the WCB outflow region is well reproduced by REF, with horizontal wind speed values close to those measured, with a bias of $0.5 \mathrm{~m} \mathrm{~s}^{-1}$ and a root mean square error of $3.3 \mathrm{~m} \mathrm{~s}^{-1}$ (Fig. 3b). The simulation provides a complete description of the jet stream and reveals two intensity maxima, hereafter called jet stream cores. The first is located at $z \approx 8 \mathrm{~km}$ between 43 and $40^{\circ} \mathrm{W}$ and the second at $z \approx 9 \mathrm{~km}$ between 37 and $31^{\circ} \mathrm{W}$. The value of the horizontal wind speed in these two cores locally exceeds $40 \mathrm{~m} \mathrm{~s}^{-1}$ (in red). The low-level jet is also well reproduced in REF. The black dots show the position of the selected ascents (that fulfill the ascent criterion of $150 \mathrm{hPa}$ in $12 \mathrm{~h}$ ) in the cross section at 11:00 UTC. A large number of ascents are located above the Greenland Plateau and the low-level jet. Many ascents are also located in the cloudy area, mainly in the eastern part. They are separated in two distinct layers. Most are located in the upper layers, between $\approx 4$ and $10 \mathrm{~km}$ altitude, within regions of large wind speed corresponding to the eastern jet stream core. The other ascents are located in the lower layers, below $z=4 \mathrm{~km}$ altitude, near regions of high reflectivity. In NODIA, the jet stream and the low-level jet are both less intense (Fig. 3c). The maximum value is equal to $38 \mathrm{~m} \mathrm{~s}^{-1}$, a value lower than the maximum of $42 \mathrm{~m} \mathrm{~s}^{-1}$ obtained for REF. The western jet stream core is less spatially extended, while the eastern jet stream core is shifted eastward. Thus, cloud diabatic processes strengthen the jet stream and modify its location in this case. In NODIA, only the ascents above the Greenland Plateau and the low-level jet are present. They are not studied afterwards in order to focus on the ascents of diabatic origin in REF.

\subsection{Analysis of the western jet stream core}

The western jet stream core, and its representation in simulations, is further investigated with help of the four dropsondes launched along the 11:00 UTC leg (see Fig. 1a). The vertical profiles of horizontal wind speed, potential temperature $(\theta)$ and relative humidity $(\mathrm{RH})$ are shown in Fig. 4 from west to east. The two westernmost dropsondes (at 43.3 and $41.8^{\circ} \mathrm{W}$ ) were launched over the Greenland Plateau, so their profiles stop at an altitude close to $2 \mathrm{~km}$. The other two dropsondes (at 40.7 and $39.2^{\circ} \mathrm{W}$ ) were launched along the Greenland coast over the western edge of the cloudy area.

The horizontal wind speed profile measured at $43.3^{\circ} \mathrm{W}$ shows a peak of $\approx 35 \mathrm{~m} \mathrm{~s}^{-1}$ at $z=8 \mathrm{~km}$ (black line in Fig. 4a). At 41.8 and $40.7^{\circ} \mathrm{W}$, the horizontal wind speed reaches $42 \mathrm{~m} \mathrm{~s}^{-1}$ and extends vertically from 8 to $10 \mathrm{~km}$ in altitude (black lines in Fig. $4 \mathrm{~b}$ and c). At $39.2^{\circ} \mathrm{W}$, it peaks again at $35 \mathrm{~m} \mathrm{~s}^{-1}$ at these heights (black line in Fig. 4d). This zonal variation validates the existence of the simulated western jet stream core seen in Fig. 3b. Its height and intensity are well reproduced by REF, though with slightly underesti- mated peaks (red lines in Fig. 4a-d), while it is slower by up to $\approx 10 \mathrm{~m} \mathrm{~s}^{-1}$ in NODIA (orange lines in Fig. $4 \mathrm{a}-\mathrm{d}$ ). Below the jet stream, the horizontal wind speed decreases down to $z \approx 7 \mathrm{~km}$ at the western dropsonde location and $z \approx 5 \mathrm{~km}$ at the eastern dropsonde location in both observation and simulations. The horizontal wind speed then varies from 5 to $20 \mathrm{~m} \mathrm{~s}^{-1}$ until $z \approx 2 \mathrm{~km}$. A second peak of horizontal wind speed of $25 \mathrm{~m} \mathrm{~s}^{-1}$ is measured in the lower troposphere by the two easternmost dropsondes (around $z=2 \mathrm{~km}$ in Fig. $4 \mathrm{c}$ and $z=1 \mathrm{~km}$ in Fig. 4d). This corresponds to the presence of the low-level jet described in Fig. 3a. The low-level jet is also well reproduced in the two simulations (red and orange lines in Fig. 4c and d) albeit $1 \mathrm{~km}$ lower. Overall, the bias \pm the root mean square error is $-0.4 \pm 5.1 \mathrm{~m} \mathrm{~s}^{-1}$ for REF and $-0.7 \pm 5.6 \mathrm{~m} \mathrm{~s}^{-1}$ for NODIA.

The measured $\theta$ profiles show a slight increase with altitude from $\approx 280 \mathrm{~K}$ in the lower levels to $\approx 300 \mathrm{~K}$ at $z=$ $6 \mathrm{~km}$ (black lines in Fig. $4 \mathrm{e}-\mathrm{h}$ ). At $43.3^{\circ} \mathrm{W}, \theta$ increases sharply above to reach $325 \mathrm{~K}$ at $z=9 \mathrm{~km}$ (Fig. 4e). This layer of high increase in $\theta$ corresponds to the location of the tropopause fold. This is well reproduced by the simulations (red and orange lines in Fig. 4e). At 41.8 and $40.7^{\circ} \mathrm{W}$, $\theta$ slightly increases from $z \approx 7 \mathrm{~km}$ before increasing abruptly again at $z \approx 9.5 \mathrm{~km}$ in both the observations and simulations (Fig. 4f and g). This indicates the presence of a second tropopause level, which is in addition to the one located at $z \approx 6 \mathrm{~km}$. This is consistent with the locations of the simulated stratospheric PV values and the dynamical tropopause height at the location of the dropsondes. At $39.2^{\circ} \mathrm{W}, \theta$ increases slightly up to $330 \mathrm{~K}$ at $z \approx 9.5 \mathrm{~km}$ before increasing suddenly above (Fig. 4h). This altitude corresponds to the dynamical tropopause height at the location of the dropsonde and is also reproduced by the simulations. The bias \pm the root mean square error is $1.7 \pm 2.2 \mathrm{~K}$ for $\mathrm{REF}$ and $-0.6 \pm 2.4 \mathrm{~K}$ for NODIA.

The RH profile at $43.3^{\circ} \mathrm{W}$ shows values of less than $20 \%$ above a $7 \mathrm{~km}$ altitude in both the observation and simulations (Fig. 4i). This confirms the absence of high clouds on the western edge of the cross section. Below, $\mathrm{RH}$ reaches larger values, up to $100 \%$ and more, at $z=4 \mathrm{~km}$. This highlights the location of mid-level clouds over the Greenland Plateau. The measured supersaturation is not reproduced by the simulations because of a saturation adjustment in the microphysical scheme. The RH profiles of the other three dropsondes show high values (close to $100 \%$ ) above $z=7 \mathrm{~km}$ (Fig. $4 \mathrm{j}-1$ ). They correspond to the cirrus-type clouds observed in Fig. 2a. A sharp decrease in RH (from $100 \%$ to $20 \%$ ) is measured between $\approx 5<z<7, \approx 4<z<7$ and $\approx 3<z<6 \mathrm{~km}$ at $41.8,40.7$ and $39.2^{\circ} \mathrm{W}$, respectively. This is consistent with the location of the dry air mass observed by RASTA and simulated in REF. This decrease in RH is not reproduced in NODIA, which matches the absence of the dry air mass in Fig. 2c. The fact that the observations are well simulated in REF and not in NODIA allows for the attribution of features to diabatic processes. Below the 


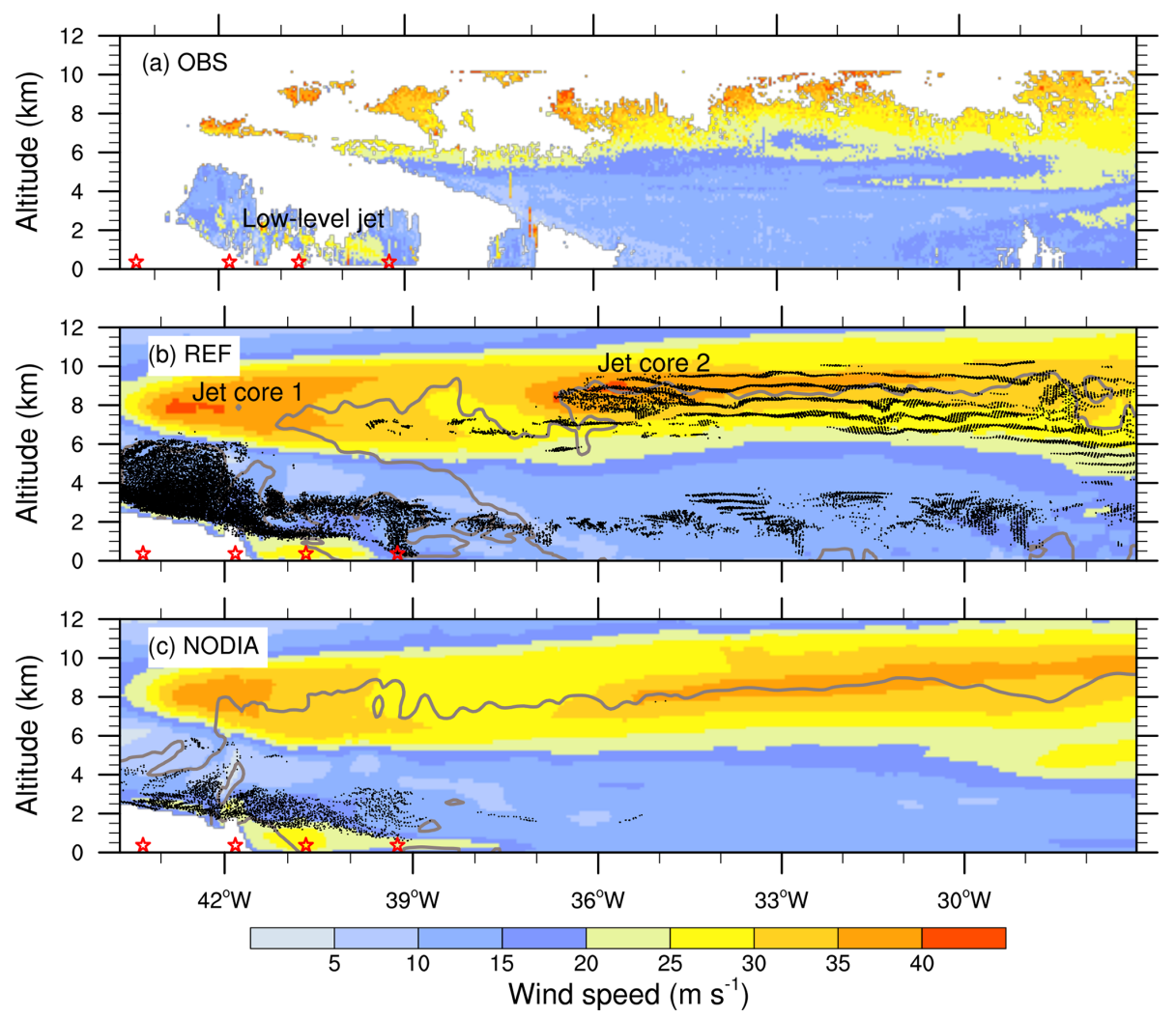

Figure 3. Horizontal wind speed (in $\mathrm{m} \mathrm{s}^{-1}$ ) (a) measured by RASTA and simulated by (b) REF and (c) NODIA along the 11:00 UTC leg (black line in Fig. 1). The red stars indicate the position of the dropsondes shown in Fig. 4. In (b) and (c), the black dots indicate the position of the selected ascents (see text for details), and the gray lines show the condensed water content equal to $0.02 \mathrm{~g} \mathrm{~kg}^{-1}$.

dry air mass, the RH shows values close to $100 \%$, referring to isolated convective structures along the Greenland coast in Fig. $2 \mathrm{a}$ and $\mathrm{b}$. The bias \pm the root mean square error is $3.5 \pm 18.6 \%$ for REF and $13.2 \pm 26.7 \%$ for NODIA. Overall, the measured vertical profiles complement the RASTA observations and are consistent with the vertical structures simulated in REF.

\section{Evolution of ascents in the WCB outflow}

\subsection{Selection of ascents}

To investigate the dynamics of simulated trajectories belonging to the WCB outflow, air parcels are first selected, if they respect the ascent criterion of $150 \mathrm{hPa}$, between 00:00 and 12:00 UTC on 2 October. Their location is compared at 11:00 UTC between REF and NODIA (Fig. 5).

In REF, three regions are highlighted with high number of ascents (in blue and green in Fig. 5a). The first region is located to the north of the cyclone center and corresponds to the WCB outflow region overflown by the aircraft (as shown in Sect. 3.2). The red box is used as a mask to select the ascents located there at 11:00 UTC. The second region is located in the southwestern part of the domain and is associated with the cloud head region. The tightening of iso- $\theta_{e}$ contours in this region shows the winding of the bent-back front around the cyclonic center, where some local peaks of the ascent number are located. Some ascents are identified further westward. The third region is located in the northwestern part of the domain, above Greenland.

In NODIA, only two regions are highlighted with high number of ascents, namely Greenland and the bent-back front region (Fig. 5b). Thus, ascents in these two regions have a dynamic origin. Those above Greenland are as numerous as in REF and are likely produced by the combined effect of the warm front dynamics and orographic forcing caused by the Greenland Plateau. A higher number of ascents is even identified compared to REF along the bent-back front, between $54-56^{\circ} \mathrm{N}$ and $35-30^{\circ} \mathrm{W}$. In contrast, ascents are almost lacking in the WCB outflow region (red box), which indicates their diabatic origin. This absence of trajectories rising by at least $150 \mathrm{hPa}$ in $12 \mathrm{~h}$ is consistent with lower cloud tops in NODIA than in REF. In the following, only ascents from this region are further discussed. 

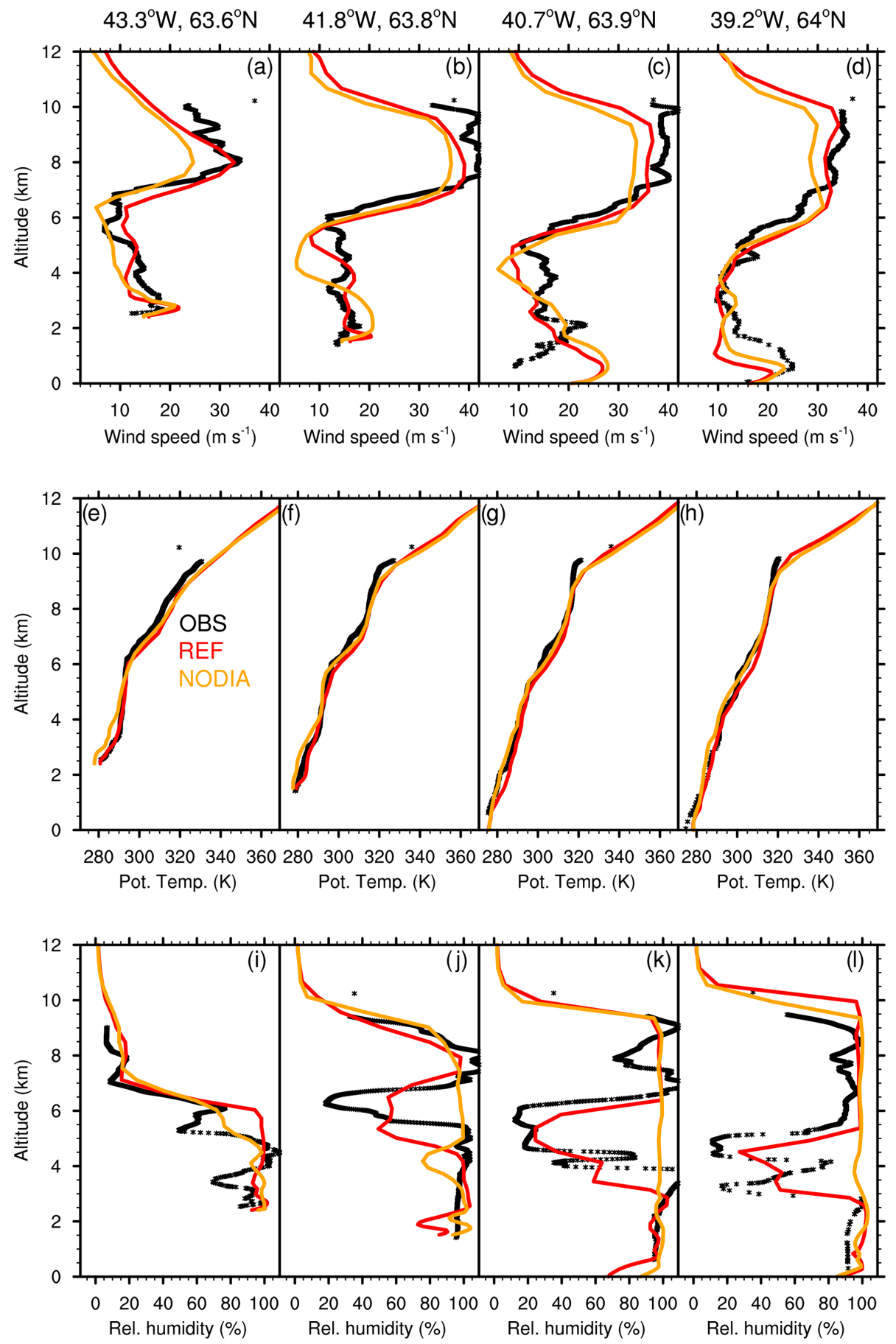

Figure 4. Profiles of (a-d) wind speed, $(\mathbf{e}-\mathbf{h})$ potential temperature and (i-l) relative humidity at the following coordinates: $(\mathbf{a}, \mathbf{e}, \mathbf{f}) 43.3^{\circ} \mathrm{W}$, $63.6^{\circ} \mathrm{N} ;(\mathbf{b}, \mathbf{f}, \mathbf{j}) 41.8^{\circ} \mathrm{W}, 63.8^{\circ} \mathrm{N} ;(\mathbf{c}, \mathbf{g}, \mathbf{k}) 40.7^{\circ} \mathrm{W}, 63.9^{\circ} \mathrm{N}$; and $(\mathbf{d}, \mathbf{h}, \mathbf{l}) 39.2^{\circ} \mathrm{W}, 64^{\circ} \mathrm{N}$. The dropsondes were launched at $10: 26,10: 32$, 10:36 and 10:41 UTC, respectively. Their location is shown as white stars in Fig. 1a. The measurements by dropsondes are shown with black lines, and the REF and NODIA simulations are shown with red and orange lines, respectively. 


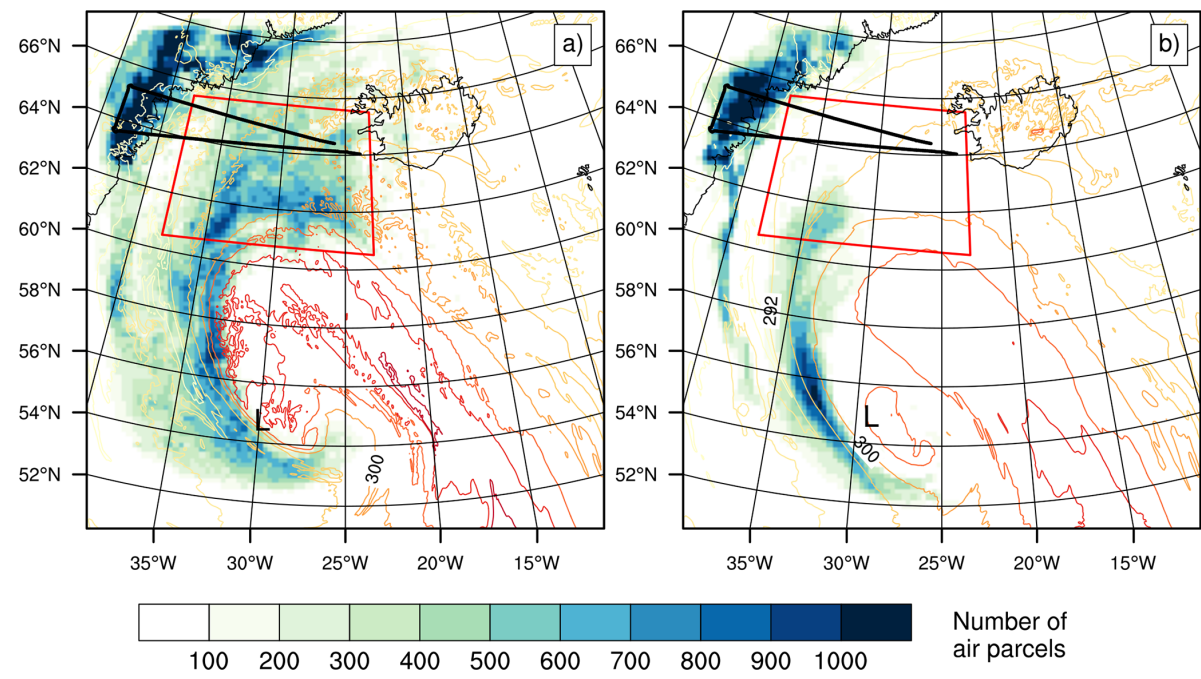

Figure 5. Number of air parcels belonging to the ascents fulfilling the ascent criterion (shading) and $\theta_{e}$ at $1 \mathrm{~km}$ altitude (colored lines every $4 \mathrm{~K}$ between 288 and $312 \mathrm{~K}$ ) at 11:00 UTC, simulated by (a) REF and (b) NODIA. The black line shows the track of the Falcon 20 aircraft, $\mathrm{L}$ the low-pressure center and the red box shows the region where the ascents are selected at 11:00 UTC.

\subsection{Location of the selected ascents}

The ascents simulated by REF in the WCB outflow region at 11:00 UTC are now examined. Anticyclonic trajectories are distinguished from cyclonic trajectories based on their curvature between 06:00 and 12:00 UTC. An overview is presented in Fig. 6 by showing samples, colored by altitude, between 00:00 and 12:00 UTC.

At 00:00 UTC, most anticyclonic ascents are located along a band extending from $\approx 56^{\circ} \mathrm{N}$ and $\approx 30^{\circ} \mathrm{W}$ to $\approx 53^{\circ} \mathrm{N}$ and $\approx 22^{\circ} \mathrm{W}$ (red stars in Fig. 6a). Their position corresponds to the location of the bent-back front at this time (not shown). The majority of cyclonic ascents also start along this band, while some start further north (red stars in Fig. 6b). At 06:00 UTC, all the ascents have been advected northward by the large-scale flow (black dots in Fig. 6a and b). Most of the anticyclonic ascents end in the eastern part of the 11:00 UTC leg (brown circles in Fig. 6a). A few of them end further north. Some cyclonic ascents also end in the eastern part of the 11:00 UTC leg but the majority end further south (brown circles in Fig. 6b).

The anticyclonic ascents are higher in altitude than the cyclonic ascents. They are located between $\approx 4000<z<$ $7000 \mathrm{~m}$ at 00:00 UTC (in light blue and green in Fig. 6a) and $\approx 7000<z<10000 \mathrm{~m}$ at 12:00 UTC (in orange). In contrast, the cyclonic ascents remain below $z \approx 5000 \mathrm{~m}$, between 00:00 and 12:00 UTC (in blue in Fig. 6c). Thus, the anticyclonic ascents correspond to the ascents found at 11:00 UTC in the eastern jet stream core (Fig. 3b) and the cyclonic ascents to those found in the lower layers. The ascents with an anticyclonic curvature are similar to the anticyclonic branch of the WCB (Martínez-Alvarado et al., 2014). They are therefore expected to impact the upper-level ridge via the injection of low-PV air in the WCB outflow region.

\subsection{Properties of the selected ascents}

The anticyclonic and cyclonic trajectories are further investigated with the help of time evolutions along the selected ascents in REF. The $2 \mathrm{~h}$ part of the trajectories which undergo an ascent greater than $100 \mathrm{hPa}$ are also discussed and are referred to as rapid segments thereafter. Overall, there are about as many anticyclonic ascents $(53 \%)$ as there are cyclonic ascents $(47 \%)$.

As already illustrated, anticyclonic ascents are located at higher altitudes than cyclonic ascents (Fig. 7a). The interquartile ranges (shading) do not overlap. The anticyclonic ascents (in blue) are located at $z \approx 4 \mathrm{~km}$ at 00:00 UTC and rise continuously until $z \approx 7 \mathrm{~km}$ at 12:00 UTC, on average. Some exceed $z=8 \mathrm{~km}$ at the end of the trajectory. Anticyclonic rapid segments are more numerous at the beginning of the trajectories and take place at around $z=4 \mathrm{~km}$ (black box plots in Fig. 7a). Their numbers then decrease with time. This suggests strong mid-level convective activity in the first hours of simulation, close to the region identified as red stars at 00:00 UTC in Fig. 6a. The cyclonic ascents (in orange) are located at $z \approx 1 \mathrm{~km}$ at 00:00 UTC, on average. Contrary to the anticyclonic ascents, they stay at a similar altitude, until 04:00 UTC, before rising to $z \approx 3 \mathrm{~km}$ (on average) at 12:00 UTC. The cyclonic rapid segments occur later than the anticyclonic rapid segments (red box plots in Fig. 7a). They are also located at lower altitudes, at around $z=2 \mathrm{~km}$. This suggests the presence of shallow convective activity at that time. 


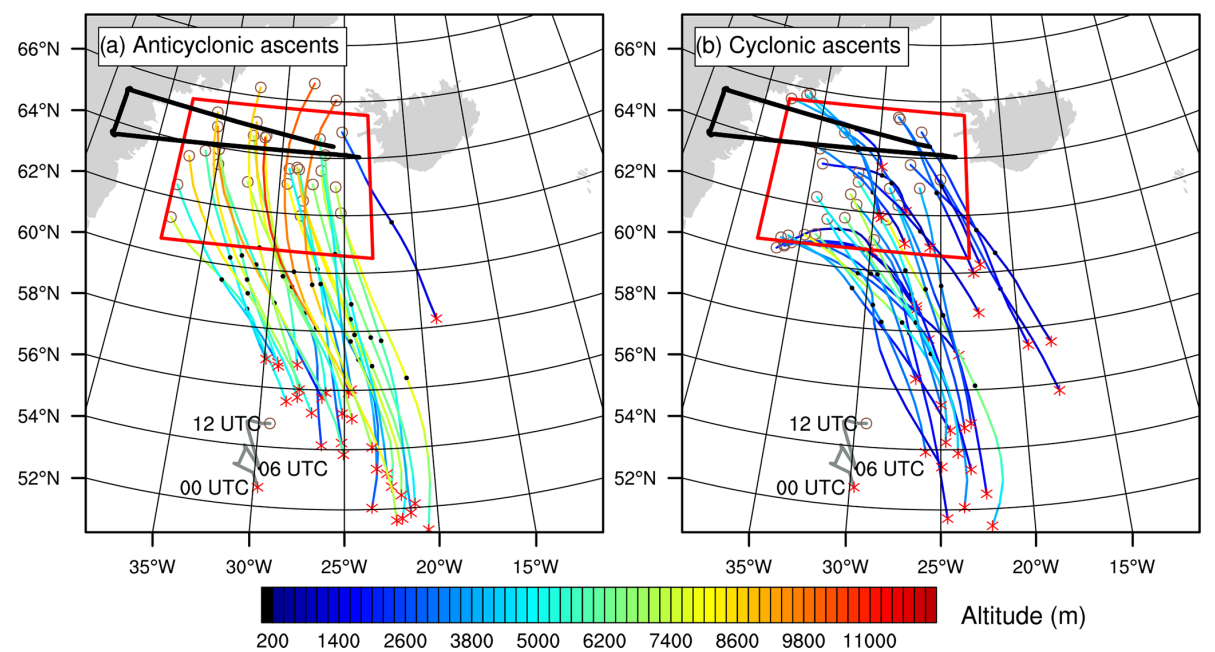

Figure 6. Selected trajectories colored by altitude, between 00:00 and 12:00 UTC, for (a) anticyclonic ascents and (b) cyclonic ascents simulated by REF. Only 30 trajectories (out of 220000 anticyclonic ascents and out of 250000 cyclonic ascents) are plotted for each category of ascents. A red cross, a black dot and a brown circle show the location of each trajectory at 00:00, 06:00 and 12:00 UTC, respectively. The black line shows the track of the Falcon 20 aircraft, the gray line the position of the MSLP minimum and the red box the region where the ascents are selected at 11:00 UTC.
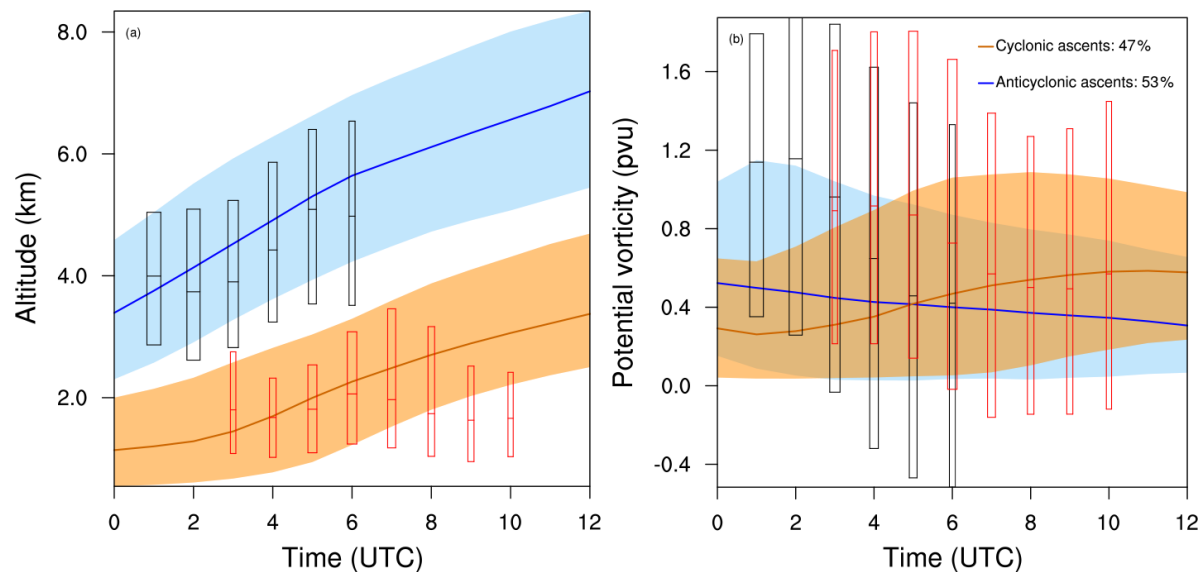

Figure 7. Time evolution of (a) altitude (in kilometers) and (b) PV (in PVU) between 00:00 and 12:00 UTC along the selected trajectories in REF. The median (colored bold line) and the 25th-75th percentiles (shading) are shown for cyclonic (orange) and anticyclonic (blue) ascents. The median and the 25 th-75th percentiles are shown with box plots for the $2 \mathrm{~h}$ rapid cyclonic (red) and anticyclonic (black) segments. Box plots are displayed only where the number of rapid segments lies above their time average, and their width is scaled with this number.

Potential vorticity decreases slowly along the anticyclonic ascents, with PV values ranging from 0.6 PVU at 00:00 UTC to $0.4 \mathrm{PVU}$ at 12:00 UTC on average (Fig. 7b). The interquartile range shows $\mathrm{PV}$ values reaching 1.2 PVU at 02:00 UTC and $0.0 \mathrm{PVU}$ during the $12 \mathrm{~h}$ period (blue shading). In contrast, the averaged PV value along the cyclonic ascents first remains at around 0.3 PVU and then increases between 04:00 and 08:00 UTC when the rapid cyclonic segments occur. As for the anticyclonic ascents, the interquartile range shows PV values between 0.0 and 1.2 PVU (orange shading). This contrasting PV evolution between the lower and upper levels of the troposphere corresponds to the classical view of
Wernli and Davies (1997) for slantwise ascents, where PV increases below the diabatic heating maximum and decreases above. However, an increasing fraction of rapid segments in particular anticyclonic ones - indicate negative PV values from 03:00 UTC onward. This suggests that convection - especially occurring at mid levels - is associated with negative $\mathrm{PV}$ creation. The origin of this process is detailed in the following section, which thus focuses on convective anticyclonic ascents. 


\section{Origin of updrafts and negative PV}

\subsection{Negative PV bands at upper levels}

The region of the ridge that was observed at 11:00 UTC is followed back in time on the $\theta=320 \mathrm{~K}$ isentropic level and compared between REF and NODIA to investigate the evolution of differences between the simulations. PV values larger and smaller than $2 \mathrm{PVU}$ indicate stratospheric and tropospheric air, respectively (white and colored shading in Fig. 8), while the jet stream follows the tropopause where the $\mathrm{PV}$ gradient is strongest (red arrows).

At 11:00 UTC, the ridge in REF largely covers the northeastern part of the domain (Fig. 8a). Above the Greenland Plateau, stratospheric air corresponds to the upper part of the tropopause fold, as shown in Fig. 2b. Further east, the $\mathrm{PV}$ tongue with stratospheric air cuts the northwestern edge of the ridge in two parts where the horizontal wind speeds exceed $45 \mathrm{~m} \mathrm{~s}^{-1}$, corresponding to the two jet stream cores described in Fig. 3b. Elongated negative PV bands (in blue) are simulated in the eastern part in a region that coincides with the location of upper-level anticyclonic ascents (see brown circles in Fig. 6a). A second region with elongated negative $\mathrm{PV}$ bands is simulated further south, along another jet stream core (between $54-58^{\circ} \mathrm{N}$ and $22-15^{\circ} \mathrm{W}$ ). This second region was overflown at 16:00 UTC by the Falcon 20 aircraft and is further described in Blanchard et al. (2020).

In NODIA, the northwestern edge of the ridge and the PV tongue are shifted eastward compared to REF (Fig. 8b). The negative PV bands are not reproduced by NODIA, neither in this region nor in the second region further south. This reveals that the elongated negative PV bands are created by cloud diabatic processes. The wind speed is less intense in the two jet stream cores, as already shown in Fig. 3c. Following the ridge, the jet stream is also less curved to the west.

At 06:00 UTC, the ridge is located further south in the domain (Fig. 8c and d). Its western part extends until $40^{\circ} \mathrm{W}$ in both REF and NODIA, but the part to the east of the PV tongue extends further west in REF compared to NODIA. The elongated negative PV bands in REF are more concentrated here than at 11:00 UTC and push the ridge to the west. Once again, they are not reproduced in NODIA and the jet stream is less intense than in REF. At 02:00 UTC, the ridge does not differ much between the two simulations (Fig. 8e and f). This is understandable as this time is close to the initialization of the simulations, and it means that the cloud diabatic processes have not yet strongly influenced the upper-level dynamics. In particular, negative PV structures are found in both simulations at that time and are already present in the initial conditions (not shown).

Overall, the comparison between REF and NODIA shows the impact of cloud diabatic processes that occurred in the WCB on the upper-level dynamics. These processes create negative PV bands that persist over time and are found at the northwestern edge of the ridge at the time of observa- tions. The negative PV bands reinforce the PV gradient at the tropopause level and, thus, the jet stream.

\subsection{Origin of the negative PV bands}

The origin of the negative PV bands is now investigated in the region where both the anticyclonic ascents start (red stars in Fig. 6a) and the elongated negative PV bands found in the WCB outflow region appear to form (box in Fig. 8e). Furthermore, time evolutions have shown that anticyclonic rapid segments are most numerous during the early simulation hours (see black box plots in Fig. 7a). Firstly, at 02:00 UTC in REF, rapid segments are examined along anticyclonic ascents, while the creation of negative PV is assessed at upper levels (Fig. 9). Secondly, the results are compared with those of NODIA to highlight the impact of cloud diabatic processes on upper-level dynamics (Fig. 10). For easier interpretation, only coherent negative PV structures are discussed here and are defined as objects with PV values less than -1 PVU. Using the same clustering approach, coherent updrafts are identified as objects with vertical wind speed values greater than $0.3 \mathrm{~m} \mathrm{~s}^{-1}$.

Most anticyclonic rapid segments in REF are located along the bent-back front, above a region of high $\theta_{e}$ values and with high $\theta_{e}$ gradients, at 02:00 UTC (black dots in Fig. 9a). Similarly, coherent updrafts are located along the bent-back front at lower and mid levels (shading). Some anticyclonic rapid segments are also located further southwestward (around $56^{\circ} \mathrm{N}$ and $30-31^{\circ} \mathrm{W}$ ) but are less numerous and not discussed here. A meridionally oriented vertical cross section illustrates that anticyclonic rapid segments are mainly located between $\approx 1$ and $\approx 4 \mathrm{~km}$ altitude along the bent-back front (black dots in Fig. 9b), where vertical wind speeds from 0.1 to $0.5 \mathrm{~m} \mathrm{~s}^{-1}$ are simulated (shading in Fig. 9b). These ascents correspond to the lower-level updrafts in Fig. 9a and originate from the frontal uprising, highlighted by the tightening of iso- $\theta_{e}$ contours in the lower layers (black lines in Fig. 9b). Anticyclonic rapid ascents are also identified at higher altitudes within two convective cells of vertical velocity close to $1 \mathrm{~m} \mathrm{~s}^{-1}$. The first cell is located between 4 and $\approx 7 \mathrm{~km}$ altitude around $56.5^{\circ} \mathrm{N}$ and the second between 4 and $\approx 6 \mathrm{~km}$ altitude around $57^{\circ} \mathrm{N}$. They both lie in a region of vertically homogeneous $\theta_{e}$ values, which promotes conditional instability. These mid-level convective cells correspond to the mid-level updrafts in Fig. 9a. A third cell of relatively high vertical wind speed is located between 6 and $\approx 9.5 \mathrm{~km}$ altitude, around $57^{\circ} \mathrm{N}$ (Fig. 9b), but it does not meet the criteria of $100 \mathrm{hPa}$ in $2 \mathrm{~h}$ for rapid segments (see Blanchard et al., 2020, for a discussion).

The top altitude of negative PV structures is shown at 02:00 UTC in Fig. 9c (shading) along with the jet stream (black lines). The location of negative PV structures is consistent with updrafts and anticyclonic rapid segments at 02:00 UTC, which follow the eastern edge of the jet stream at upper levels and the bent-back front at lower levels. The 

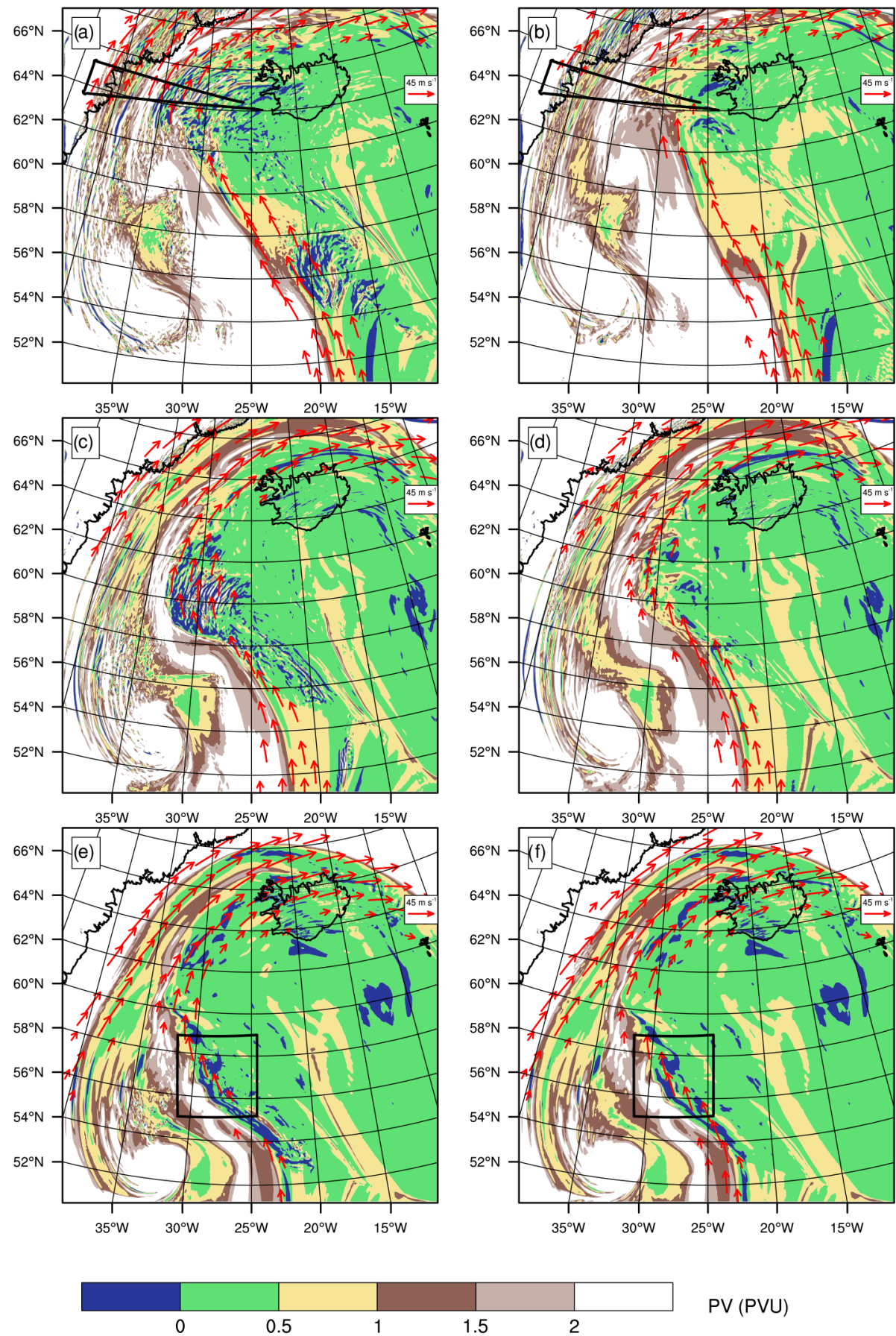

Figure 8. PV (shading) and wind above $45 \mathrm{~m} \mathrm{~s}^{-1}$ (red arrows) on the $320 \mathrm{~K}$ level at (a, b) 11:00, (c, d) 06:00 and (e, f) 02:00 UTC simulated by $(\mathbf{a}, \mathbf{c}, \mathbf{e})$ REF and $(\mathbf{b}, \mathbf{d}, \mathbf{f})$ NODIA. The black line $(\mathbf{a}, \mathbf{b})$ shows the track of the Falcon 20 aircraft, and the box (e, f) indicates the area that has been magnified for Figs. 9 and 10.

vertical cross section reveals the presence of mesoscale horizontal PV dipoles around the first and second mid-level convective cells (Fig. 9d). They are located above a low-level jet and below the upper-level jet stream. The negative PV poles are facing the jet stream core and reach values lower than $-2 \mathrm{PVU}$, while the positive PV poles reach values larger than
2 PVU. This description is coherent with the findings of Oertel et al. (2020) and Blanchard et al. (2020). Note the absence of a PV dipole for the strong updraft above $6 \mathrm{~km}$ altitude that does not meet the criteria for rapid segments. Strong positive PV values are also visible in the low-level jet, below the anticyclonic rapid segments. This corresponds to the classical 

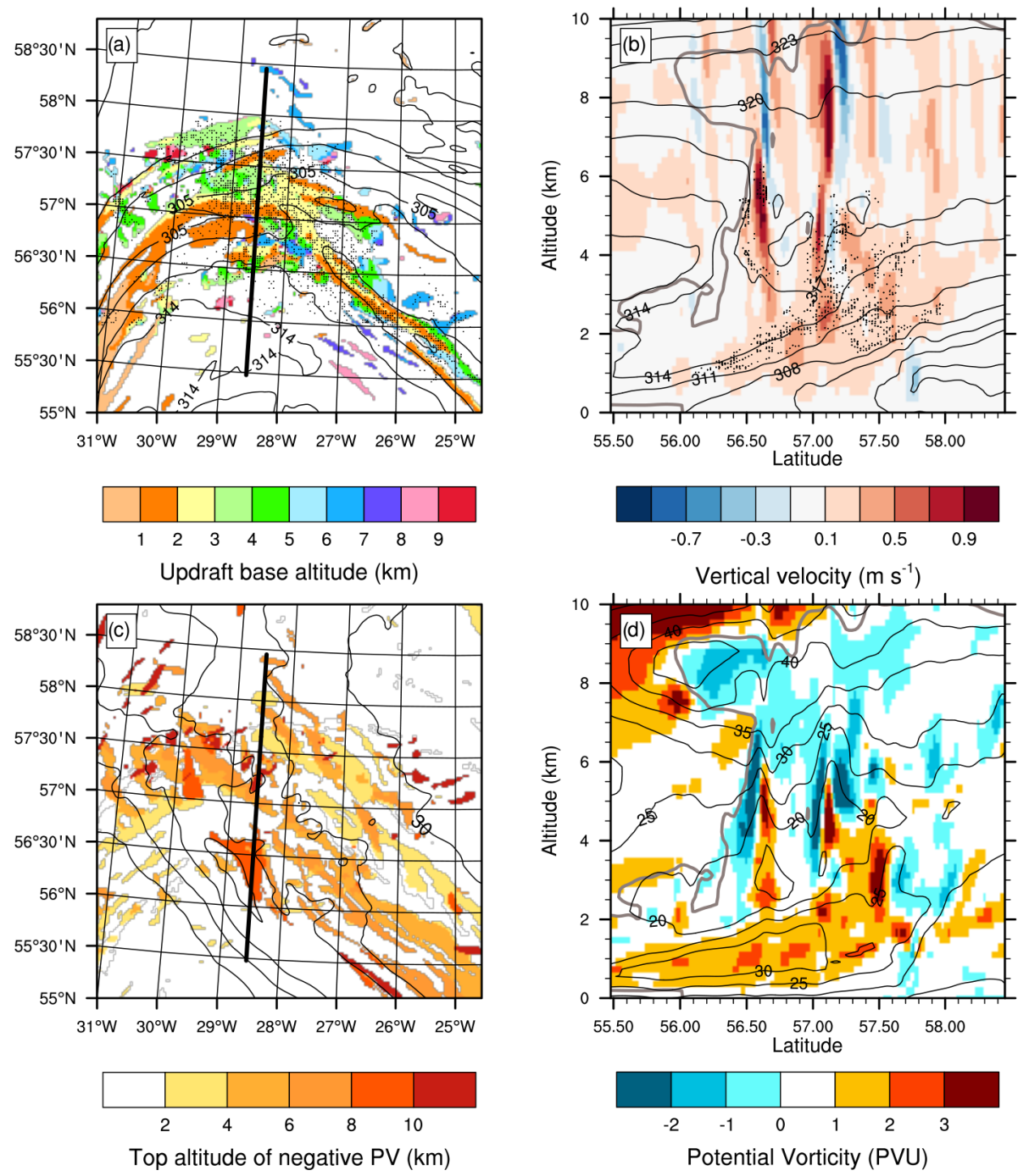

Figure 9. Results at 02:00 UTC for the REF simulation. (a) Base altitude of updrafts (shading; in kilometers) and $\theta_{e}$ at $1 \mathrm{~km}$ height (black contours every $3 \mathrm{~K}$ ). (b) Vertical velocity (shading; in $\mathrm{m} \mathrm{s}^{-1}$ ), $\theta_{e}$ (black contours every $3 \mathrm{~K}$ ) and cloud variables (thick gray contour above $0.1 \mathrm{~g} \mathrm{~kg}^{-1}$ ) along the vertical cross section illustrated in panel (a). (c) Top altitude of negative PV structures (shading; in kilometers) and horizontal wind speed on the $320 \mathrm{~K}$ level (contours every $5 \mathrm{~K}$ above $30 \mathrm{~m} \mathrm{~s}^{-1}$ ). (d) PV (shading; in PVU), horizontal wind speed (black contours every $5 \mathrm{~K}$ ) and cloud variables (thick gray contour above $0.1 \mathrm{~g} \mathrm{~kg}^{-1}$ ) along the vertical cross section illustrated in panel (b). Dots $(\mathbf{a}, \mathbf{b})$ indicate the location of rapid anticyclonic segments, reduced to one for every 10, in panel (a).

view of Wernli and Davies (1997), i.e., a vertical PV dipole with positive anomaly below the maximum level of diabatic heating.

The same fields are shown for NODIA, also at 02:00 UTC and in the same area (Fig. 10). The bent-back front is less pronounced and the corresponding updrafts are absent in NODIA (Fig. 10a). Only about 10 coherent updrafts are located at upper levels. Moreover, no anticyclonic rapid segments are present. This is consistent with the absence of convective cells in the vertical cross-section and is explained by the greater stability of the middle layers compared to REF, in particular at the southern edge of the cloudy area (Fig. 10b). Negative PV structures are also rare in NODIA (Fig. 10c).
A few are present at upper levels, along the eastern edge of the jet stream, and are inherited from the initial conditions. The vertical cross-section illustrates the absence of horizontal PV dipoles in the mid-level troposphere (Fig. 10d). Negative PV values close to the jet stream core (around $z=9 \mathrm{~km}$ at $\approx 56.50^{\circ} \mathrm{N}$ ) and positive $\mathrm{PV}$ values in the low-level jet are both weaker compared to REF. The impact on the dynamics is contrasted at this time, as the jet stream core is not yet impacted, while the low-level jet has less intense horizontal winds.

To summarize, the comparison between REF and NODIA shows the influence of cloud diabatic processes, which are at the origin of mid-level convective cells within the cloud 

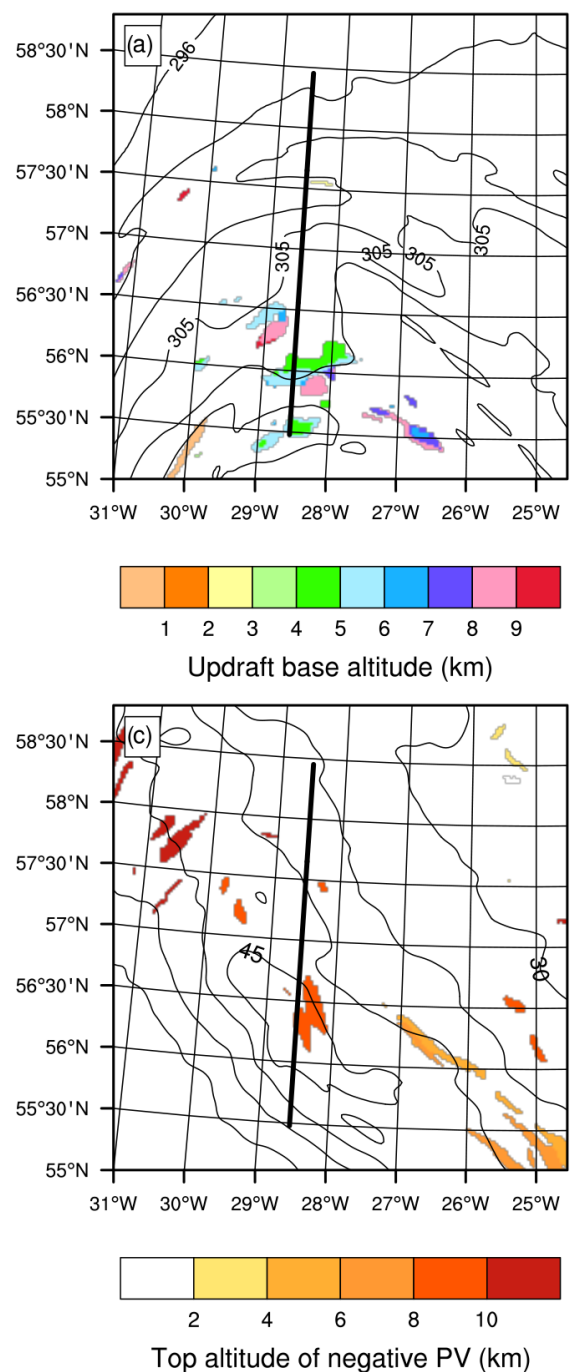

Figure 10. As in Fig. 9 but for the NODIA simulation.

region. These cells diabatically create horizontal PV dipoles at mid levels, with a pole reaching strongly negative values lower than -2 PVU. Negative PV structures then persist with time and participate in the westward extension of the ridge and the associated tightening of tropopause PV gradients, which result in the strengthening of the upper-level jet.

\section{Conclusions}

This paper focuses on the WCB outflow associated with the Stalactite cyclone located close to the Icelandic coast on 2 October 2016. To this end, fine-scale observations of upperlevel dynamics in the WCB outflow region were performed using the RASTA radar during a flight of the Falcon 20 aircraft operated during the NAWDEX field campaign. In addition, in situ measurements of cloud structure and dynamics were provided by four dropsondes launched from the Fal-
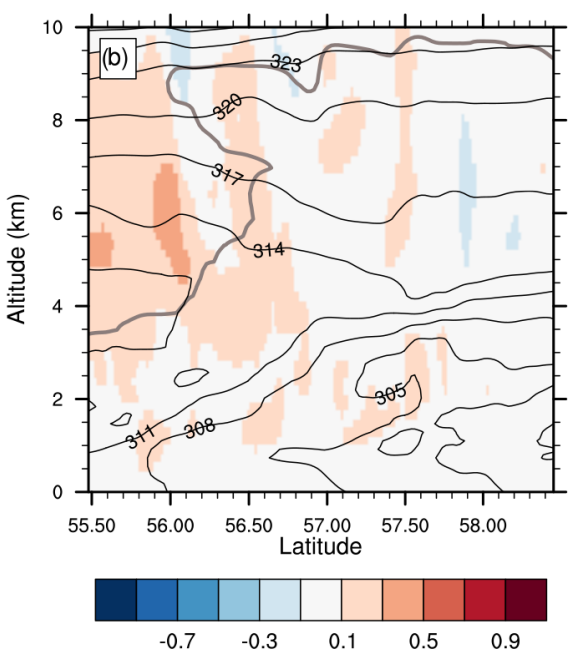

Vertical velocity $\left(\mathrm{m} \mathrm{s}^{-1}\right)$

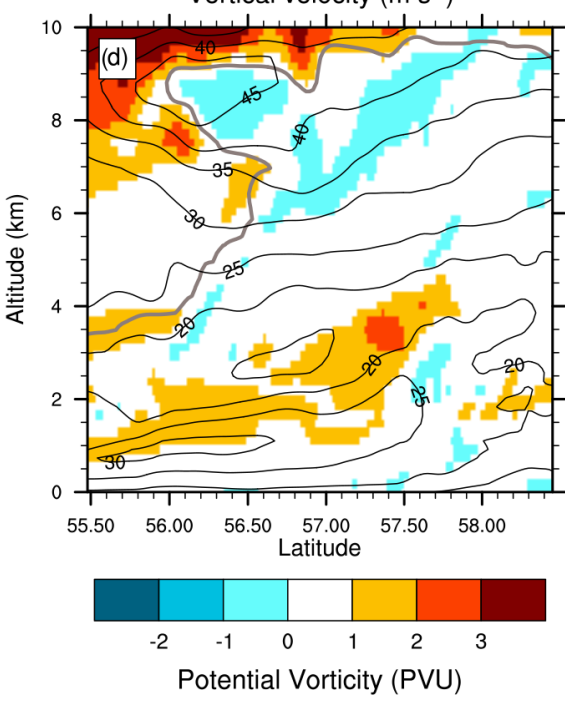

con 20. The observations are combined with results from two Meso-NH convection-permitting simulations of the cyclone during its mature phase. The first is defined as the reference simulation (REF), while in the second simulation (NODIA), heat exchanges from cloud processes are set to zero in the microphysical scheme. The main cloud structures observed by the MSG satellite are well simulated on a kilometer scale in REF, whereas the cloud tops are generally $1 \mathrm{~km}$ too low in NODIA. Moreover, an abrupt eastward shift in the cyclone's trajectory, according to the ECMWF analysis, is well captured by REF but is not reproduced by NODIA.

RASTA observations show structures with low and high reflectivity values in the upper and lower troposphere, respectively. They thus highlight the presence of cirrus-type clouds in the WCB outflow region and convective activity within the WCB and above the Greenland Plateau. These observations, combined with dropsonde measurements, also reveal the existence of a dry air mass between the warm front 
and the Greenland Plateau. The reflectivity structures simulated in REF are in agreement with the observations, while the cloud tops are lower and the dry air mass is absent in NODIA (cutting off the diabatic cooling reduces evaporation of frozen hydrometeors under the warm front). Two regions of low dynamical tropopause are found in the simulations, namely a PV tongue that cuts the northwestern edge of the ridge in two parts and a tropopause fold at the edge of the outer part, while local structures of negative PV are found in the inner part. In NODIA, the dynamical tropopause is lower than in REF, the tropopause fold and the PV tongue are shifted eastward and negative PV structures are rarer.

RASTA also measures an increase in horizontal wind speed with altitude, with values locally exceeding $40 \mathrm{~m} \mathrm{~s}^{-1}$ associated with the jet stream at around $z=8 \mathrm{~km}$. A lowlevel jet is observed along the Greenland coast, with horizontal wind speed at about $25 \mathrm{~m} \mathrm{~s}^{-1}$ below $z=2 \mathrm{~km}$. REF completes the measurements by highlighting the presence of two jet stream cores located near the tropopause fold and near the $\mathrm{PV}$ tongue. NODIA also simulates two jet stream cores but with lower intensity and shifted towards the east. Similarly, the low-level jet is well reproduced in REF but is weaker in NODIA. Dropsonde observations confirm the existence of the western jet stream core and the tropopause fold found in the simulations. They also agree with the low-level jet and dry air mass measured by RASTA.

Air parcels undergoing an ascent of at least $150 \mathrm{hPa}$ in $12 \mathrm{~h}$ are identified in REF and NODIA with online Lagrangian trajectories. In REF, three main regions of ascents appear at the time of the observations. They are associated with the WCB outflow region, the cloud head and the Greenland Plateau. In contrast, only ascents located in the cloud head and above the Greenland Plateau are simulated in NODIA. They thus have a dynamical origin, due to a combination of orographic forcing and frontal dynamics, while ascents in the WCB outflow do not occur in the absence of cloud diabatic processes.

The ascents that end in the WCB outflow region are further separated between anticyclonic and cyclonic curvatures, which are approximately equally represented. Most of them start in the same region near the cyclone's bent-back front, with the anticyclonic ascents being higher than the cyclonic ascents. The anticyclonic ascents end in the northwestern edge of the ridge at high altitudes and are reminiscent of the anticyclonic branch of the WCB (Martínez-Alvarado et al., 2014). The cyclonic ascents stay in the lower levels during the $12 \mathrm{~h}$ window and end further south. The rapid segments - defined as the portion of the ascents that rise by at least $100 \mathrm{hPa}$ in $2 \mathrm{~h}$ - occur mainly in the middle troposphere along the anticyclonic ascents in the first hours of simulation and in the lower troposphere along cyclonic ascents later on. The time evolution of PV shows an increase along cyclonic ascents and a slow decrease along anticyclonic ascents. It is consistent with the vertical dipole of PV anomalies centered around the level of maximum diabatic heating described in
Wernli and Davies (1997) for slantwise ascents. However, not only low but also negative PV values are reached by rapid, especially anticyclonic segments, suggesting a convective origin as in Oertel et al. (2020).

In a comparative evolution between REF and NODIA, the northwestern edge of the ridge consistently extends further west by about $100 \mathrm{~km}$, and the corresponding jet stream core is more intense and meandering. This confirms that cloud diabatic processes may reinforce the ridge and the jet stream in the WCB outflow region, as found in previous studies (e.g., Chagnon et al., 2013; Schemm et al., 2013; Joos and Forbes, 2016; Maddison et al., 2020). Furthermore, elongated negative PV bands are simulated in this region in REF but not in NODIA. Such negative PV bands were also found by Blanchard et al. (2020) along the flank of a jet stream core for the same case study. Here, the comparison between REF and NODIA highlights that they are diabatically produced, which is in agreement with recent studies using mesoscale simulations and observations (Oertel et al., 2020; Harvey et al., 2020). The negative PV bands originate from the same region as anticyclonic ascents ending in the WCB outflow region, which leads us to further examine their potential link.

During the first hours of the REF simulation, a clustering analysis identifies the updraft objects above the bentback front whose location matches the anticyclonic rapid segments at that time. Negative PV structures are located in the same region at mid and upper levels. While the identified updrafts in the lower layers are due to frontal dynamics and are characterized by a relatively low vertical velocity of about $0.3 \mathrm{~m} \mathrm{~s}^{-1}$, in the middle levels they take the form of convective cells and reach about $1 \mathrm{~m} \mathrm{~s}^{-1}$. These cells are located at the western edge of the cloudy area, below the jet stream core and above the low-level jet, in a region of conditional instability. This description matches the organized mid-level convection in the WCB region found by Blanchard et al. (2020). In addition, horizontal PV dipoles are found around the mid-level convective cells with the negative pole facing the jet stream, which confirms the theory developed in Harvey et al. (2020) and the findings of Oertel et al. (2020). In contrast, updraft objects and negative PV structures are absent from NODIA, mid-level convective cells and horizontal PV dipoles.

Overall, the results highlight that negative PV structures in WCB ascent regions are diabatically created by midlevel convection. These structures are then transported by the anticyclonic flow into the northwestern edge of the ridge, where they persist for about $10 \mathrm{~h}$ before dispersing. During this time, they participate in extending the ridge westward, strengthening PV gradients at the tropopause level and intensifying the jet stream. The results thus suggest that mid-level convection contributes to ridge building and questions its role in large-scale dynamics. As parameterization schemes often struggle to represent updrafts that do not start in the boundary layer (e.g., McTaggart-Cowan et al., 2020), the representation of mid-level convection may be a source of uncertainty 
for the prediction of the downstream atmospheric circulation in global models.

Code and data availability. The Meso-NH code is available at http: //mesonh.aero.obs-mip.fr/ (last access: 1 December 2020) (MESONH, 2020). RASTA data are available from Julien Delanoë upon request.

Author contributions. NB performed the simulations and the analyses under the supervision of FP and JPC. JD provided the observations, and all authors prepared the paper.

Competing interests. The authors declare that they have no conflict of interest.

Acknowledgements. Computer resources were allocated by GENCI (project 90569). We thank the two anonymous reviewers for their comments, which helped to improve the overall quality of the paper.

Financial support. The research leading to these results has received funding from the ANR-17-CE01-0010 DIP-NAWDEX project. The SAFIRE Falcon contribution to NAWDEX received direct funding from L'Institut Pierre-Simon Laplace (IPSL), MétéoFrance, Institut National des Sciences de l'Univers (INSU, via the LEFE program), EUFAR Norwegian Mesoscale Ensemble and Atmospheric River Experiment (NEAREX) and ESA (EPATAN; contract no. 4000119015/16/NL/CT/gp).

Review statement. This paper was edited by Lukas Papritz and reviewed by two anonymous referees.

\section{References}

Blanchard, N., Pantillon, F., Chaboureau, J.-P., and Delanoë, J.: Organization of convective ascents in a warm conveyor belt, Weather Clim. Dynam., 1, 617-634, https://doi.org/10.5194/wcd-1-617-2020, 2020.

Browning, K. A.: Mesoscale Aspects of Extratropical Cyclones: An Observational Perspective, in: The Life Cycles of Extratropical Cyclones, edited by, Shapiro, M. A. and Grønås S., American Meteorological Society, Boston, MA, 265-283, https://doi.org/10.1007/978-1-935704-09-6_18, 1999.

Chagnon, J. M., Gray, S. L., and Methven, J.: Diabatic processes modifying potential vorticity in a North Atlantic cyclone, Q. J. Roy. Meteorol. Soc., 139, 1270-1282, https://doi.org/10.1002/qj.2037, 2013.

Colella, P. and Woodward, P. R.: The Piecewise Parabolic Method (PPM) for gas-dynamical simulations, J. Comput. Phys., 54, 174-201, https://doi.org/10.1016/0021-9991(84)90143-8, 1984.
Dauhut, T., Chaboureau, J.-P., Escobar, J., and Mascart, P.: Giga-LES of Hector the Convector and its two tallest updrafts up to the stratosphere, J. Atmos. Sci., 73, 5041-5060, https://doi.org/10.1175/JAS-D-16-0083.1, 2016.

Delanoë, J., Protat, A., Jourdan, O., Pelon, J., Papazzoni, M., Dupuy, R., Gayet, J.-F., and Jouan, C.: Comparison of airborne in situ, airborne radar-lidar, and spaceborne radar-lidar retrievals of polar ice cloud properties sampled during the POLARCAT campaign, J. Atmos. Ocean Tech., 30, 57-73, https://doi.org/10.1175/JTECH-D-11-00200.1, 2013.

Gheusi, F. and Stein, J.: Lagrangian description of airflows using Eulerian passive tracers, Q. J. Roy. Meteorol. Soc., 128, 337360, https://doi.org/10.1256/00359000260498914, 2002.

Grams, C. M., Wernli, H., Böttcher, M., Čampa, J., Corsmeier, U., Jones, S. C., Keller, J. H., Lenz, C.-J., and Wiegand, L.: The key role of diabatic processes in modifying the upper-tropospheric wave guide: a North Atlantic case-study, Q. J. Roy. Meteorol. Soc., 137, 2174-2193, https://doi.org/10.1002/qj.891, 2011.

Gray, S. L., Dunning, C. M., Methven, J., Masato, G., and Chagnon, J. M.: Systematic model forecast error in Rossby wave structure, Geophys. Res. Lett., 41, 2979-2987, https://doi.org/10.1002/2014GL059282, 2014.

Harrold, T. W.: Mechanisms influencing the distribution of precipitation within baroclinic disturbances, Q. J. Roy. Meteorol. Soc., 99, 232-251, https://doi.org/10.1002/qj.49709942003, 1973.

Harvey, B., Methven, J., Sanchez, C., and Schäfler, A.: Diabatic generation of negative potential vorticity and its impact on the North Atlantic jet stream, Q. J. Roy. Meteorol. Soc., 146, $1477-$ 1497, https://doi.org/10.1002/qj.3747, 2020.

Hoskins, B. J. and Ambrizzi, T.: Rossby Wave Propagation on a Realistic Longitudinally Varying Flow, J. Atmos. Sci., 50, 1661-1671, https://doi.org/10.1175/15200469(1993)050<1661:RWPOAR>2.0.CO;2, 1993.

Hoskins, B. J., McIntyre, M. E., and Robertson, A. W.: On the use and significance of isentropic potential vorticity maps, Q. J. Roy. Meteorol. Soc., 111, 877-946, https://doi.org/10.1002/qj.49711147002, 1985.

Joos, H. and Forbes, R. M.: Impact of different IFS microphysics on a warm conveyor belt and the downstream flow evolution, Q. J. Roy. Meteorol. Soc., 142, 2727-2739, https://doi.org/10.1002/qj.2863, 2016.

Lac, C., Chaboureau, J.-P., Masson, V., Pinty, J.-P., Tulet, P., Escobar, J., Leriche, M., Barthe, C., Aouizerats, B., Augros, C., Aumond, P., Auguste, F., Bechtold, P., Berthet, S., Bieilli, S., Bosseur, F., Caumont, O., Cohard, J.-M., Colin, J., Couvreux, F., Cuxart, J., Delautier, G., Dauhut, T., Ducrocq, V., Filippi, J.B., Gazen, D., Geoffroy, O., Gheusi, F., Honnert, R., Lafore, J.-P., Lebeaupin Brossier, C., Libois, Q., Lunet, T., Mari, C., Maric, T., Mascart, P., Mogé, M., Molinié, G., Nuissier, O., Pantillon, F., Peyrillé, P., Pergaud, J., Perraud, E., Pianezze, J., Redelsperger, J.-L., Ricard, D., Richard, E., Riette, S., Rodier, Q., Schoetter, R., Seyfried, L., Stein, J., Suhre, K., Thouron, O., Turner, S., Verrelle, A., Vié, B., Visentin, F., Vionnet, V., and Wautelet, P.: Overview of the Meso-NH model version 5.4 and its applications, Geosci. Model Dev., 11, 19291969, https://doi.org/10.5194/gmd-11-1929-2018, 2018.

Maddison, J. W., Gray, S. L., Martínez-Alvarado, O., and Williams, K. D.: Upstream Cyclone Influence on the Predictability of Block 
Onsets over the Euro-Atlantic Region, Mon. Weather Rev., 147, 1277-1296, https://doi.org/10.1175/MWR-D-18-0226.1, 2019.

Maddison, J. W., Gray, S. L., Martínez-Alvarado, O., and Williams, K. D.: Impact of model upgrades on diabatic processes in extratropical cyclones and downstream forecast evolution, Q. J. Roy. Meteorol. Soc., 146, 1322-1350, https://doi.org/10.1002/qj.3739, 2020.

Martínez-Alvarado, O., Joos, H., Chagnon, J., Boettcher, M., Gray, S. L., Plant, R. S., Methven, J., and Wernli, H.: The dichotomous structure of the warm conveyor belt, Q. J. Roy. Meteorol. Soc., 140, 1809-1824, https://doi.org/10.1002/qj.2276, 2014.

Martínez-Alvarado, O., Maddison, J. W., Gray, S. L., and Williams, K. D.: Atmospheric blocking and upper-level Rossby-wave forecast skill dependence on model configuration, Q. J. Roy. Meteorol. Soc., 144, 2165-2181, https://doi.org/10.1002/qj.3326, 2018.

McTaggart-Cowan, R., Vaillancourt, P. A., Separovic, L., Corvec, S., and Zadra, A.: A Convection Parameterization for LowCAPE Environments, Mon. Weather Rev., 148, 4917-4941, https://doi.org/10.1175/MWR-D-20-0020.1, 2020.

MESO-NH: Welcome, available at: http://mesonh.aero.obs-mip.fr/, last access: 1 December 2020.

Oertel, A., Boettcher, M., Joos, H., Sprenger, M., and Wernli, H.: Potential vorticity structure of embedded convection in a warm conveyor belt and its relevance for large-scale dynamics, Weather Clim. Dynam., 1, 127-153, https://doi.org/10.5194/wcd-1-1272020, 2020.

Schäfler, A., Craig, G., Wernli, H., Arbogast, P., Doyle, J. D., McTaggart-Cowan, R., Methven, J., Rivire, G., Ament, F., Boettcher, M., Bramberger, M., Cazenave, Q., Cotton, R., Crewell, S., Delanoë, J., Dörnbrack, A., Ehrlich, A., Ewald, F., Fix, A., Grams, C. M., Gray, S. L., Grob, H., Groß, S., Hagen, M., Harvey, B., Hirsch, L., Jacob, M., Kölling, T., Konow, H., Lemmerz, C., Lux, O., Magnusson, L., Mayer, B., Mech, M., Moore, R., Pelon, J., Quinting, J., Rahm, S., Rapp, M., Rautenhaus, M., Reitebuch, O., Reynolds, C. A., Sodemann, H., Spengler, T., Vaughan, G., Wendisch, M., Wirth, M., Witschas, B., Wolf, K., and Zinner, T.: The North Atlantic Waveguide and Downstream Impact Experiment, B. Am. Meteorol. Soc., 99, 16071637, https://doi.org/10.1175/BAMS-D-17-0003.1, 2018.
Schäfler, A., Harvey, B., Methven, J., Doyle, J. D., Rahm, S., Reitebuch, O., Weiler, F., and Witschas, B.: Observation of Jet Stream Winds during NAWDEX and Characterization of Systematic Meteorological Analysis Errors, Mon. Weather Rev., 148, 2889 2907, https://doi.org/10.1175/MWR-D-19-0229.1, 2020.

Schemm, S., Wernli, H., and Papritz, L.: Warm Conveyor Belts in Idealized Moist Baroclinic Wave Simulations, J. Atmos. Sci., 70, 627-652, https://doi.org/10.1175/JAS-D-12-0147.1, 2013.

Söhne, N., Chaboureau, J.-P., and Guichard, F.: Verification of cloud cover forecast with satellite observation over West Africa, Mon. Weather Rev., 136, 4421-4434, https://doi.org/10.1175/2008MWR2432.1, 2008.

Steinfeld, D., Boettcher, M., Forbes, R., and Pfahl, S.: The sensitivity of atmospheric blocking to upstream latent heating numerical experiments, Weather Clim. Dynam., 1, 405-426, https://doi.org/10.5194/wcd-1-405-2020, 2020.

Wernli, H. and Davies, H. C.: A Lagrangian-based analysis of extratropical cyclones. I: The method and some applications, Q. J. Roy. Meteorol. Soc., 123, 467-489, https://doi.org/10.1002/qj.49712353811, 1997. 